\title{
Siluro-Devonian of Podolia, Ukraine: Paleobiological, biostratigraphic, and geochemical aspects
}

Hubert Szaniawski

Acta Palaeontologica Polonica 57 (4), 2012: 793-794 doi: http://dx.doi.org/10.4202/app.2012.1002

Hubert Szaniawski [szaniaw @twarda.pan.pl], Instytut Paleobiologii PAN, ul. Twarda 51/55, PL-00-818 Warszawa, Poland.

This is an open-access article distributed under the terms of the Creative Commons Attribution License (for details please see creativecommons.org), which permits unrestricted use, distribution, and reproduction in any medium, provided the original author and source are credited.

Fofif Full text $(629.0 \mathrm{kB})$ 